\title{
TEORI EVOLUSI DARWIN: DULU, KINI DAN NANTI
}

\author{
Leo Muhammad Taufik \\ Prodi Pendidikan IPA, Muhammadiyah Cirebon, Indonesia \\ E-mail: leotaufik.edu@gmail.com
}

\begin{abstract}
Abstrak
Perkembangan ilmu tidak terlepas dari kemajuan teknologi begitu pula perkembangan teori Evolusi sebagai cabang dari ilmu Biologi yang sampai saat ini terus mengalami perkembangan. Walaupun banyak menimbulkan kontroversi, sampai saat ini teori evolusi Darwin dipandang memiliki keunggulan dibanding teori evolusi lainnya karena Darwin berhasil memperlihatkan datadata empiris terjadinya proses evolusi yang mengarah pada diversitas organisme. Artikel ini membahas teori evolusi Darwin sebagai bagian dari filsafat sains sesuai bukti- bukti pendukungnya. Berdasar hasil kajian dan analisis, teori evolusi Darwin hingga saat ini masih layak digunakan dan berkesesuaian dengan teori lainnya.
\end{abstract}

Kata Kunci: Teori Darwin, Epistemologi; Teori Evolusi; Ontologi Teori Evolusi

\begin{abstract}
The development of science is inseparable from technological advances as well as the development of the theory of Evolution as a branch of the science of Biology which until now continues to develop. Although there are many controversies, up to now Darwin's theory of evolution is considered to have advantages over other evolutionary theories because Darwin succeeded in showing empirical data on the evolutionary process that leads to the diversity of organisms. This article discusses Darwin's theory of evolution as part of the philosophy of science in accordance with supporting evidence. Based on the results of studies and analysis, Darwin's theory of evolution is still suitable to be used and in accordance with other theories.
\end{abstract}

Keyword: Darwin's theory'; Epistemologi; Evolutionary Theory; Ontology evolutionary Theory

\section{Pendahuluan}

Apakah evolusi benar-benar terjadi? Pertanyaan ini mengundang banyak persepsi yang sulit untuk diterima oleh semua golongan. Teori tentang evolusi seringkali menjadi bahan perdebatan sekaligus mengundang penolakan dari berbagai golongan terutama dari golongan agamawan. Alasan penolakan tersebut tidak lain karena evolusi dianggap bertentangan dengan dalil yang tercantum dalam kitab suci yang mereka yakini. Kemunculan dan perkembangan teori evolusi tidak bertujuan untuk membuat manusia meragukan kebenaran kitab suci yang diyakininya akan tetapi justru dapat memperkuat keyakinan seseorang terhadap kebenaran agamanya. Sebagaimana Iskandar (2008) menyatakan bahwa teori evolusi tidak bertentangan dengan agama mana pun di dunia. Perdebatan yang selama ini terjadi disebabkan karena keterbatasan ilmu pengetahuan itu sendiri. Namun seiring dengan perkembangan ilmu pengetahuan dan teknologi, teori evolusi pun mengalami perkembangan menurut masanya.

Pada masa evolusi modern seperti saat ini telah banyak sarana serta konsep-konsep yang menunjang kemajuan teori evolusi. Kemajuan di bidang genetika, biokimia dan molekuler turut menyumbangkan konsep-konsep yang mendorong pada perkembangan teori evolusi khususnya dalam, memetakan materi genetik dari fosil-fosil yang ditemukan di lapisan bumi tertentu, pewarisan sifat serta kekerabatan antar organisme ditinjau dari persentase persamaan materi genetiknya. Semakin besar persentase persamaan matergi genetiknya maka kekerabatan organisme yang diperbandingkan tersebut dapat disimpulkan semakin dekat.

Perkembangan teknologi komputer dan informatika berhasil menuntun sains untuk melacak bukti-bukti empiris tentang kehidupan masa lampau sehingga terjadinya evolusi tidak diragukan lagi pertanggungjawabannya secara ilmiah. Dengan semakin banyaknya bukti-bukti baru yang ditemukan, semakin besar pencerahan yang kita dapatkan dalam menyibak misteri evolusi makhluk hidup. Kini, kita tidak bisa lagi mengingkari ketika sains sampai pada kesimpulan 
bahwa bumi dan kehidupan di atasnya merupakan produk dari evolusi, termasuk manusia sebagai sang khalifah di muka bumi.

Sebagai cabang ilmu Biologi kajian evolusi terfokus pada perubahan struktur organisme yang terjadi secara berangsur menuju kesesuaian fungsi dengan waktu dan tempat hidupnya. Bertolak dari batasan tersebut, banyak muncul anggapan bahwa evolusi hanya terjadi dalam jangka waktu yang sangat lama. Lamanya waktu yang dibutuhkan untuk terjadinya perubahan organisme seringkali menjadi pembeda istilah evolusi dengan revolusi dalam ilmu sosial. Istilah revolusi merujuk pada perubahan yang terjadi dalam tempo yang relatif cepat. Lalu apakah mikroorganisme yang dapat mengalami perubahan dalam waktu relatif cepat dapat disebut sebagai evolusi?

Fenomena yang terjadi dewasa ini menunjukkan bahwa evolusi mikroorganisme dapat terjadi hanya dalam jangka waktu satu tahun (Mader \& Windelspecht, 2018) dan manusia turut andil dalam mempercepat proses evolusi. Salah satu jenis mikroba yang diketahui mengalami evolusi dalam kisaran tahun adalah strain virus $\mathrm{H} 5 \mathrm{~N} 1$ yaitu virus penyebab penyakit flu burung. Data menunjukkan bahwa virus H5N1 yang pertama kali menyebabkan kematian di Indonesia yaitu pada tahun 2005 setelah sebelumnya ditemukan di Hongkong tahun 1997. Pada tahun 2018 harian Republika edisi 17 Februari 2018 mewartakan bahwa strain virus penyebab flu burung telah berubah menjadi H7N4. Apakah perubahan yang terjadi pada virus tersebut dapat dikategorikan sebagai evolusi? Jika dalam hitungan beberapa tahun saja virus dapat dikategorikan mengalami evolusi jadi berapakah batasan waktu yang dibutuhkan untuk terjadinya evolusi makhluk hidup?

Pemahaman mengenai teori evolusi memberikan pandangan baru tentang cara menyikapi evolusi mikroba dalam jangka waktu yang singkat. Sebagai contoh, dokter tidak akan memberikan antibiotik kepada pasiennya hingga benar-benar diketahui bahwa pasiennya terinfeksi jenis bakteri spesifik. Berdasarkan hal tersebut perlu kita pelajari bukti-bukti empiris yang terjadi serta mekanisme proses evolusi terjadi.

\section{Metode}

Metode yang digunakan adalah studi literatur terkait teori evolusi Darwin beserta buktibukti empiris yang mendukungnya. Artikel ini memberikan pemahaman pragmatis mengenai bagaimana teori evolusi berlaku di era modern saat ini.

\section{Hasil dan Pembahasan Isu-Isu pokok Evolusi: Konsep Inti Biologi}

Teori evolusi identik dengan Darwin, walapun sebenarnya gagasan evolusi pertama kali bukan diperkenalkan oleh Darwin, tetapi kita dapat menelusurinya hingga zaman Yunani kuno. Thales (636 - 546 SM) dan Anaximander (611 - 547 SM) biasa memperbincangkan asal usul biota laut dan evolusi kehidupan. Phytagoras (570 - 496 SM), Xantus (kira-kira 500 SM) dan Empedocles (490 - $430 \mathrm{SM}$ ) juga membicarakan isu yang sama dalam tulisan-tulisan mereka (Comas, 1957 dalam Risatasa, 2013). Plato (427-347 SM) percaya bahwa benda-benda yang diamati hanyalah tiruan (copy) dari dunia ide di keabadian yang tidak dapat dilihat. Agar mengerti dunia seseorang harus berkontemplasi prinsip-prinsip umum di sebalik hal yang diamati (Firman, 2019). Plato berpendapat bahwa dengan adanya evolusi, akan mengubah dunia yang organismenya sudah ideal dan beradaptasi sempurna terhadap lingkungannya. Berbeda dengan Aristoteles (384-322 SM) murid dari Plato, yang berargumen bahwa pengetahuan tentang dunia datang melalui pengalaman yang diinterpretasi nalar (reason) (Firman, 2019). Aristoteles menganut teori skala alami (scalae naturae) dimana skala alami membahas bahwa adanya klasifikasi bentuk kehidupan berdasarkan tingkat kompleksitas. Aristoteles meyakini bahwa spesies sudah berada dalam bentuk permanen, sempurna, dan tidak berkembang lagi.

Evolusi merupakan proses perubahan spesies dalam jangka waktu tertentu yang bertujuan agar mampu beradaptasi terhadap lingkungannya dan meneruskan perubahan tersebut kepada generasi berikutnya (Campbell, 2003). Evolusi menjadi konsep pemersatu dalam biologi karena evolusi menjelaskan banyak aspek dalam biologi terutama bagaimana organisme yang hidup saat ini merupakan evolusi dari satu nenek moyang (ancestor) dan diversitas kehidupan yang besar di bumi ini. 
Pernyataan tersebut tidak terlepas dari teori yang melekat bersamanya. Beberapa ahli biologi seperti Charles Darwin, Alfred Russel Wallace mencoba menerangkan mengenai keberagaman makhluk hidup melalui pemikiran-pemikirannya. Charles Darwin melalui bukunya "On The Origin of Species: by Means of Natural Selection" melalui beragam fakta-fakta empiris. Buku tersebut menyajikan kasus-kasus yang meyakinkan tentang evolusi dan telah dapat menghubungkan apa yang sebelumnya dilihat sebagai suatu kumpulan fakta membingungkan dan tidak saling berkaitan menjadi suatu pandangan kohesif mengenai kehidupan. Kaum realis memiliki ketertarikan kuat terhadap teori ini karena realisme berpendapat bahwa alat indera merupakan pokok utama dalam mencari sebuah kebenaran. Berdasarkan hal tersebut kaum realis yakin akan bukti empiris mengenai teori evolusi Darwin.

\section{Teori Evolusi Darwin (Tinjauan Filsafat)}

Charles Darwin berusia sekitar 22 tahun ketika melakukan ekpedisi bersama HMS Beagle (sebuah kapal inggris yang berlayar ke seluruh dunia). Ekspedisi ini seharusnya memakan waktu dua tahun tetapi Darwin menghabiskan waktu hingga lima tahun. Selama perjalanan, Darwin berkesempatan mengumpulkan dan mengobservasi keanekaragaman hayati berdasarkan bentuknya. Pemikiran awal Darwin dipengaruhi pandangan Aristoteles adalah bahwa : "tidak ada perubahan sejak waktu kreasi bumi". Campbell (2003) memperlihatkan cara Darwin mengambil kesimpulan berdasarkan data observasi. Berikut adalah pola inferensi Darwin:

Observasi 1: Individu dalam populasi memiliki karakteristik bervariasi yang sifatnya dapat diturunkan.

Observasi 2: Organisme memproduksi keturunan lebih daripada daya dukung lingkungan

Inferensi 1: Individu yang sesuai dengan lingkungannya akan memproduksi keturunannya lebih banyak daripada individu lain.

Inferensi 2 : Seiring waktu, sifat yang menguntungkan akan terakumulasi dalam populasi.

Darwin membuat konklusi bahwa organisme yang mampu beradaptasi terhadap lingkungan mampu meneruskan sifat unggul kepada keturunannya melalui proses reproduksi. Darwin mengemukakan dua kata kunci dalam teorinya yaitu seleksi alam (natural selection) dan adaptasi (adaptation). Darwin menyadari bahwa adaptasi berkembang seiring berjalannya waktu sehingga Darwin perlu menjelaskan mekanisme evolusi. Darwin mengajukan kata "seleksi alam" sebagai mekanisme perubahan evolusioner. Beberapa langkah mekanisme seleksi alam sebagai mekanisme perubahan evolusioner adalah sebagai berikut.

1. Anggota populasi memiliki variasi sifat yang akan melewati proses seleksi alam (keadaan lingkungan yang tidak menunjang).

2. Anggota populasi yang mampu bertahan hidup (beradaptasi) akan mampu melakukan reproduksi dengan membawa sifat unggul daripada individu lain.

3. Seiring berjalan waktu, proporsi sifat yang menguntungkan (mampu beradaptasi) akan meningkat dalam populasi dan yang tidak memiliki sifat tersebut akan musnah.

Seleksi alam merupakan proses yang terus berlangsung karena lingkungan terus berubah. Kepunahan dapat terjadi bila proses adaptasi tidak sejalan dengan perubahan lingkungan. Pandangan Darwin mengenai kehidupan memiliki perbedaan yang sangat tajam dengan paradigma konvensional yang mengatakan bumi baru berumur beberapa ribu tahun saja, dihuni oleh bentuk-bentuk kehidupan yang tidak berubah dan telah diciptakan satu per satu selama seminggu penuh di mana Sang Pencipta membentuk keseluruhan jagad raya sehingga Darwin perlu berhati-hati dalam menyampaikan gagasannya (Campbell, 2003).

Beberapa filsuf Yunani mulai meyakini terjadinya evolusi kehidupan secara bertahap, akan tetapi Plato (1427 - 347 SM) dan muridnya Aristoteles (384 - 322 SM) yang merupakan dua filsuf yang paling berpengaruh dalam kebudayaan barat, tetap memegang pendapat yang bertentangan dengan konsep evolusi. Plato sangat meyakini tentang dua dunia: dunia nyata yang ideal dan kekal dengan dunia khayal yang tidak sempurna yang kita tangkap melalui panca indera kita. Evolusi akan kontra produktif di dalam suatu dunia di mana organisme ideal sudah teradaptasikan secara sempurna terhadap lingkungannya. Aristoteles yakin bahwa semua bentuk kehidupan dapat disusun dalam suatu skala, dengan tingkat kerumitan yang semakin tinggi yang kemudian dikenal sebagai skala alam (scale of natural). Menurutnya, tiap-tiap bentuk kehidupan memiliki anak tangga yang telah ditentukan untuknya pada tangga tersebut dan setiap anak tangga ini telah terisi. Dalam pandangan ini, spesies bersifat permanen, sempurna dan tidak berkembang (Risatasa, 2013). 
Dalam budaya Judeo-Kristen, Kitab Perjanjian Lama yang berisi penciptaan, dikuatkan ide bahwa setiap spesies telah diciptakan atau dirancang satu per satu dan bersifat permanen. Pada awal tahun 1700-an, biologi di Eropa dan Amerika didominasi oleh teologi alami (natural theology), yaitu suatu filosofi yang dikhususkan pada penemuan rencana Sang Pencipta dengan mempelajari alam. Para pengikut teologi alami melihat adaptasi organisme sebagai bukti Sang Pencipta telah merancang masing- masing dan setiap spesies untuk suatu tujuan tertentu. Tujuan utama teologi alami adalah untuk mengelompokkan spesies yang memperlihatkan tahapan skala kehidupan yang telah diciptakan oleh Tuhan (Risatasa, 2013).

Teori dan pemikiran Charles Darwin mengenai evolusi mahkluk hidup menggunakan kajian secara ontologi dan epistemologi, karena hasil pemikiran Charles Darwin berdasarkan pengamatan-pengamatan yang ia lakukan lalu dianalisa dan munculah konsep adaptasi dan seleksi alam. Darwin menggunakan paradigma positivistik karena teori evolusi mahkluk hidup berlandaskan data-data empiris, dapat diobservasi secara nyata, dan dibuktikan secara ilmiah. Dimensi dinamis dalam sains digambarkan oleh lahirnya teori evolusi makhluk hidup melalui metode ilmiah yang menggambarkan sains sebagai sebuah proses. Hal ini memberikan produk berupa teori evolusi Darwin sebagai produk dari pengkajian fenomena alam secara ilmiah. Sesuai dengan pernyataan Firman (2019) bahwa sains pada hakikatnya merupakan proses dan produk dimana produk sains adalah hasil dari proses sains itu sendiri.

Biologi mengenal kata "evolusi" yang berarti bahwa makhluk hidup mengalami perubahan (modifikasi) dari makhluk hidup sebelumnya. Implikasi hadirnya Teori evolusi tidak memperkenankan keanekaragaman hayati terjadi melalui proses revolusi. Teori evolusi sejalan dengan teori asal usul kehidupan yaitu teori biogenesis dimana makhluk hidup berasal dari makhluk hidup sebelumnya. Walaupun demikian, teori evolusi memiliki keterbatasan dalam menjelaskan asal-usul kehidupan. Teori ini pun sejalan dengan hukum Mendel yang dikemukakan pada tahun 1920-an mengenai sifat yang diturunkan kepada generasi berikutnya melalui substansi tertentu (yang akhirnya dikenal dengan sebutan "gen"). Pengurutan gen pada DNA pada akhir abad ke 20 melahirkan filogenetik molekuler dan merombak pohon kehidupan menjadi tiga sistem domain. Seiring perkembangan zaman, pandangan saintis mengenai evolusi terpusat pada gen sebagai "kode kehidupan" (Campbell, 2003).

\section{Evolusi dan Kemajuan Teknologi}

Teori evolusi Darwin menjadi landasan bagi teori evolusi modern, termasuk rekayasa genetika. Perkembangan teknologi dewasa ini memungkinkan saintis untuk melakukan rekaya genetika. Melalui rekayasa genetik, manusia berkontribusi dalam mempercepat proses evolusi (Campbell, 2003). Genetic Material Organism (GMO) merupakan hasil penggunaan teknologi terkait proses mutasi genetik yang mengarah pada evolusi suatu makhluk hidup. Sebelum rekayasa genetic ditemukan, manusia telah melakukan "rekayasa genetik" melalui peristiwa kawin silang. Perkawinan silang dilakukan manusia hingga mendapatkan organisme dengan sifat yang diinginkan manusia. Anjing merupakan contoh perkawinan silang ras serigala. Jelas penggunaan teori evolusi ditangkap dengan baik oleh para teknolog dalam rangka merekayasa materi genetika makhluk hidup sesuai keinginan dan kebutuhan manusia.

\section{Simpulan dan Saran}

Teori evolusi Darwin membantu dalam menerangkan pemikiran mengenai evolusi yang terjadi di dunia saat ini dan merupakan tonggak berkembangnya berbagai disiplin ilmu melalui inferensi berdasarkan bukti empiris. Teori evolusi Darwin ditunjang dengan berbagai bukti empiris dan diperkuat dengan teori lain sehingga mengukuhkan teori Darwin sebagai teori evolusi yang diyakini hingga saat ini. Berdasarkan teori Darwin, maka kata "evolusi" lebih tepat digunakan dalam menjelaskan keberagaman makhluk hidup daripada kata "revolusi" karena menurut teori Darwin, terdapat keterkaitan antara generasi sebelumnya dan generasi setelahnya melalui proses reproduksi. Proses evolusi makhluk hidup masih terus berlanjut hingga saat ini dan sejalan dengan seleksi alam yang terjadi. Untuk itu, perlu adanya tinjauan lebih mendalam mengenai aksiologi teori darwin. Pada dasarnya teori darwin menitikberatkan pada proses seleksi alam dan adaptasi makhluk hidup bukan pada perubahan morfologis manusia. Aksiologi perlu diperdalam terkait isu penggunaanya di tengah masyarakat agamis. 


\section{Daftar Pustaka}

Campbell, N.A., Jane B.R., Lawrence G.M. 2003. Biologi. Jakarta: Erlangga.

Iskandar, Djoko T. 2008. Evolusi. Jakarta: Universitas Terbuka. pp. 1-44.

Firman, Harry. 2019. Pengantar Filsafat IImu Pengetahuan Alam. Bandung: Sekolah Pascasarjana Universitas Pendidikan Indonesia.

Mader, S.S., Windelspecht, M. 2018. Essentials of Biology $5^{\text {th }}$ edition. New York: McGraw-Hill Education

Ramadani,A.C. 2018. Kasus Flu Burung H7N4 Pertama Pada Manusia Ditemukan di Cina. [Online]. https://www.republika.co.id/berita/gaya-hidup/info-sehat/18/02/17/p4a7tf366kasus-flu-burung-h7n4-pertama-pada-manusia-ditemukan-di-cina (diakses pada tanggal 12 November 2019).

Risatasa. 2013. Modul 1: Sejarah Perkembangan Teori Evolusi Makhluk Hidup. [Online]. http://repository.ut.ac.id/4251/1/PEBI4204-M1.pdf (diakses pada tanggal 12 November 2019). 